\title{
Contextual Effect of Posyandu on the Risk of Stunting in Children Under Five, Klaten, Central Java
}

\author{
Anna Mariyana'), Yulia Lanti Retno Dewi²), Setyo Sri Rahardjo²) \\ 1)Masters Program in Public Health, Universitas Sebelas Maret \\ ${ }^{2)}$ Faculty of Medicine, Universitas Sebelas Maret
}

\section{ABSTRACT}

Background: Stunting is a condition of failure to thrive in children under five as a result of chronic malnutrition. Environmental interventions such as water, sanitation and hygiene behavior (WASH) can be used as a strategy to reduce the high incidence of stunting. This study aims to determine environmental factors and other factors on the incidence of stunting in toddlers.

Subjects and Method: This study was an observational analytic study with a case-control approach. This research was conducted in July 2019 - August 2019 in Klaten Regency, Central Java. A total of 200 samples was selected by simple random sampling. The dependent variable was stunting. The independent variables were mother's education, family income, number of family members, water sources, sanitation, history of infectious diseases, family diet, hand washing behavior and posyandu strata. The data collection technique used a questionnaire and analyzed by a multiple multilevel logistic regression.

Results: The risk of stunting increased with low maternal education <Senior high school $(b=3.43 ; 95 \% \mathrm{CI}=1.47$ to $5.40 ; \mathrm{p}<0.001$ ), low family income $(b=2.72 ; 95 \% \mathrm{CI}=0.80$ to 4.64 ; $\mathrm{p}=0.005)$, family members $\geq 5(\mathrm{~b}=2.26 ; 95 \%$ $\mathrm{CI}=0.65$ to $3.87 ; \mathrm{p}=0.006$ ), households with open water sources $(b=2.2895 \% \mathrm{CI}=0.74$ to 3.83; $\mathrm{p}=0.004)$, inadequate sanitation $(\mathrm{b}=$ 2.66; $95 \% \mathrm{CI}=1.06$ to $4.26 ; \mathrm{p}<0.001$ ), children had a history of infectious disease $(b=2.29$; $95 \% \mathrm{CI}=0.70$ to $3.88 ; \mathrm{p}=0.005$ ), family diet $(\mathrm{b}=2.39 ; 95 \% \mathrm{CI}=0.67$ to $4.11 ; \mathrm{p}=0.006)$, and mothers did not wash their hands $(b=2.10$; $95 \% \mathrm{CI}=0.63$ to $3.56 ; \mathrm{p}=0.005$ ). Posyandu strata had strong contextual effect on stunting in children under five with intra-class correlation $($ ICC) $=34.84 \%$.

Conclusion: The risk of stunting increases with low maternal education, low family income, family members $\geq 5$, households with open water sources, inadequate sanitation, children had a history of infectious disease, family diet, and mothers did not wash their hands. Posyandu strata has strong contextual effect on stunting in children under five.

Keywords: stunting, water sources, sanitation, history of infectious diseases

\section{Correspondence:}

Anna Mariyana. Masters Program in Public Health, Universitas Sebelas Maret. Jl. Ir. Sutami 36A, Surakarta, Central Java. Email: annamariyana28.am@gmail.com.

\section{Cite this as:}

Mariyana A, Dewi YLR, Rahardjo SS (2020). Contextual Effect of Posyandu on the Risk of Stunting in Children Under Five, Klaten, Central Java. J Matern Child Health. 05(06): 725-736. https://doi.org/10.26911/thejmch.2020.05.06.12.

cc (i) (2) Journal of Maternal and Child Health is licensed under a Creative Commons EY NC SA Attribution-NonCommercial-ShareAlike 4.0 International License.

\section{BACKGROUND}

The problem of malnutrition globally can reduce the quality of human resources, so that various countries in the world work together to overcome it through the development of global nutrition, namely the
Scaling Up Nutrition (SUN) Movement. The main focus of the SUN movement is to meet nutritional needs in the first 1000 days of life to reduce stunting (Ki-Moon, 2016). Stunting is a condition of failure to thrive in children under five years of age 
(under five) as a result of long-term nutritional deficiencies, characterized by body length or height per age (HAZ) having a Zscore below - 2 Standard Deviation (SD), (Demirchyan et al., 2016). The target of the World Health Assembly (WHA) in 2025 is to reduce the number of stunted children by 40\% (Prendergast and Humphrey, 2014).

Based on data from the World Health Organization-United Nations Children's Fund (WHO-UNICEF), 159 million children under five are stunted and 51 million children under five are experiencing wasting. The 2014 Global Nutrition Report shows that Indonesia is among 17 countries out of 117 countries that have these nutritional problems (Kemenkes RI, 2016). The prevalence of stunting in Indonesia is $30.8 \%$ with the highest prevalence in East Nusa Tenggara (NTT) at 42.6\%, in Central Java the prevalence of stunting is $31.2 \%$ while in Klaten Regency, Central Java, Indonesia the prevalence of stunting is $27 \%$ (Riskesdas, 2018; Klaten Health Office, 2018).

Stunting can occur due to various influencing factors, including the lack of nutrition, starting from infancy to toddlers. Lack of breastfeeding (ASI) in the first six months, as well as improper supplementation of complementary foods (Mufida, 2015). Other factors that can affect the incidence of stunting are micronutrient deficiencies such as protein, iron, zinc and infectious diseases (Chirande et al., 2015). Characteristics of parents ranging from education, work, parenting, household economics and knowledge of nutrition also affect stunting (Ariesthi et al., 2015; Sujendran et al., 2015). Low formal education of parents can increase 4.91 times the incidence of stunted children, low parental income has an increase of 1.48 times the incidence of stunted children (Sujendran et al., 2015). The low socioeconomic level of the family makes a family unable to meet their nutri- tional needs so that it affects the increasing incidence of stunting (Vonaesch et al., 2017)

The environment in which they live also has an influence on stunting. People who live in rural areas have a 20\% higher prevalence than those who live in urban areas. Poverty, access to health services and difficult information in rural areas are the factors causing the higher rate of stunting in rural areas (Audrie et al., 2013). Open feces landfills have a higher risk of stunting in children under five compared to areas with proper latrines (Spears et al., 2013). In Indonesia 1 in 5 households still defecate openly and 1 in 3 households do not have access to clean drinking water, and hand washing behavior is still low $\left(\mathrm{TNP}_{2} \mathrm{~K}\right.$, 2017).

The health service that affects the incidence of stunting is the Integrated Service Post (Posyandu). Toddlers who rarely come to posyandu have a risk factor for stunting 9.0 times compared to those who regularly attend posyandu (Ariesthi et al., 2015). Posyandu has a contextual effect on the incidence of stunting children with ICC: $15.00 \%$, which means that the posyandu strata affect the incidence of stunting children, the posyandu level independently can reduce the incidence of stunting (Sajalia et al., 2018).

Based on various factors that influence the incidence of stunting, it is necessary to conduct research related to the influence of the environment and posyandu on the incidence of stunting in children under five.

\section{SUBJECTS AND METHOD}

\section{Study Design}

This was an analytic observational study with a case-control design. This study was conducted at integrated health posts (Posyandu) in 5 community health centers, 
Klaten, Central Java, from July to August 2019.

\section{Population and Sample}

The source population in this study were toddlers who were in 25 Posyandu from 5 different Health centers in Klaten Regency. The selection of Posyandu was carried out by stratified random sampling. A sample of 200 children under five was carried out by simple random sampling.

\section{Study Variables}

The dependent variable was stunting in children under five. The independent variables were mother's education, family income, number of family members, water sources, sanitation, history of infectious diseases, family dietary pattern, hand washing behavior, and Posyandu strata.

\section{Operational Definition of Variable}

Stunting was the nutritional status of children aged 6-59 months as measured by length or height according to age (HAZ), then compared with anthropometric standards for assessing children's nutritional status according to the Decree of the Minister of Health Number 1995/Menkes/SK/XII/ 2010.

Maternal education is the mother's last formal education that is completed until graduation.

Family income is the average income or income each month in the last six months generated by the head of the family / other family members to meet their daily needs.

The number of family members is the number of family members who live in the house.

Water source is a source of water used by a family for drinking, cooking, bathing, and washing.

Sanitation is the availability and appropriateness of sewage drains (septic tanks) and healthy latrines in the household.

Food consumption patterns are a balance between meeting the nutritional needs of a family by assessing the diversity of food consumed by the family.

Hand washing behavior is a mother's habit of washing hands using soap at home before eating, after finishing defecating and having a bowel movement, before preparing and giving baby food.

Infectious disease history is a history of infectious diseases that are being or have been suffered by children under five, such as diarrhea or respiratory infections in the last six months.

Posyandu is the type or level of posyandu that exists in the community.

\section{Instruments}

The research instrument used for data collection was a questionnaire about maternal education, family income, number of family members, water sources, sanitation, hand washing behavior and a history of infectious diseases. The Family Diet Questionnaire uses the Food Frequency Questionare (FFQ). Posyandu strata are divided into three categories, namely intermediate, full moon and independent.

\section{Data Analysis}

Univariate analysis was carried out to obtain the frequency distribution and percentage characteristics of the study subjects. Bivariate analysis was performed to analyze the relationship between the independent and dependent variables using the Chi-Square test and the calculation of the odds ratio (OR) with 95\% CI and significance level of $\mathrm{p}<0.05$. Multivariate analysis was performed using multiple multilevel logistic regression analysis.

\section{Research Ethics}

The ethics of this research include informed consent, anonymity, confidentiality, and ethical clearance. Ethical clearance was carried out at the Faculty of Medicine, Sebelas Maret University with number 275 / UN27.06 / KEPK / 2019 issued on July 8, 2019. 


\section{RESULTS}

1. Univariate Analysis

The subjects of this study consisted of 200 toddlers. Univariate analysis of variables covering maternal education, family income, number of family members, water sources, sanitation, history of infectious diseases, food consumption patterns, and hand washing behavior are described in table 1.

Table 1. Univariate Analysis of Research Subject Variables

\begin{tabular}{lcc}
\hline \multicolumn{1}{c}{ Variable } & n & \% \\
\hline Maternal Education & & 65.5 \\
High $\geq$ Senior high school & 131 & 34.5 \\
Low <SHS & 69 & 66 \\
Family Income & 132 & 34 \\
High $\geq$ Average & 68 & 62 \\
Low <Average & & 38 \\
The number of family members & 124 & \\
$<5$ & 76 & 59.5 \\
$\geq 5$ & & 40.5 \\
Water sources & 119 & 61.5 \\
Protected & 81 & 38.5 \\
Open & & \\
Sanitation & 123 & 63.5 \\
Adequate & 77 & 36.5 \\
Inadequate & & \\
History of Infectious Disease & 127 & 65 \\
No & 73 & 35 \\
Yes & & 61 \\
Food Consumption Pattern & 130 & 39 \\
Various & 70 & \\
Not diverse & & \\
Hand Washing Behavior & 122 & \\
Done & 78 & \\
Not done & & \\
\hline
\end{tabular}

Table 1 shows that mothers with high education >Senior high school are 131 (65.5\%) and mothers with low education $<$ SMA are 69 (34.5\%). Toddlers from high income families were 132 (66\%) and those with low income <average were 68 (34\%). Toddlers from the number of family members $<5$ were $124(62 \%)$ and those with $\geq 5$ family members were 78 (38\%). The number of children under five from households that have protected water sources is 119 (59.5\%) and children under five from households with open water sources are 81 (40.5\%). 123 (61.5\%) of children with ade- quate sanitation were as many as 123 (61.5\%) and households with inadequate sanitation were 77 (38.5\%). As many as 127 (63.5\%) of children under five who did not have a history of infectious diseases and 73 (36.5\%) had a history of infectious diseases. Toddlers from families with diverse food consumption patterns were as much as 130 (65\%) and toddlers from families with nondiverse food consumption patterns were as much as 70 (35\%). 122 (61\%) of mothers who wash their hands properly and 78 (39\%) who do not wash their hands properly. 


\section{Bivariate Analysis}

Bivariate analysis was performed using the Chi Square test and the calculation of the Odds Ratio (OR) with a 95\% confidence level. The results of the bivariate analysis in table 2 show the relationship of the independent variables with the dependent variable (stunting). The results of the analysis can be seen in table 2 .

Table 2. Bivariate analysis factors that influence stunting (mother's education, family income, number of family members, water sources, sanitation, history of infectious diseases, food consumption patterns and hand washing behavior)

\begin{tabular}{|c|c|c|c|c|c|c|c|c|c|}
\hline \multirow{3}{*}{ Independent Variable } & \multicolumn{4}{|c|}{ Stunting } & \multirow{2}{*}{\multicolumn{2}{|c|}{ Total }} & \multirow{3}{*}{ OR } & \multirow{3}{*}{$\begin{array}{c}(95 \%) \\
\text { CI }\end{array}$} & \multirow{3}{*}{$\mathbf{p}$} \\
\hline & \multicolumn{2}{|c|}{ No } & \multicolumn{2}{|c|}{ Yes } & & & & & \\
\hline & $\mathbf{n}$ & $\%$ & $\mathbf{N}$ & $\%$ & $\mathbf{N}$ & $\%$ & & & \\
\hline \multicolumn{10}{|l|}{ Maternal Education } \\
\hline High $>=$ SHS & 102 & 78 & 29 & 22 & 131 & 100 & \multirow[t]{2}{*}{5.15} & $2.60-$ & \multirow{2}{*}{$<0.001$} \\
\hline Low $<$ SHS & 28 & 40 & 41 & 60 & 69 & 100 & & 10.19 & \\
\hline \multicolumn{10}{|l|}{ Family Income } \\
\hline High & 107 & 81 & 25 & 19 & 132 & 100 & \multirow[t]{2}{*}{8.37} & $4.09-$ & \multirow{2}{*}{$<0.001$} \\
\hline Low & 23 & 34 & 45 & 66 & 68 & 100 & & 17.21 & \\
\hline \multirow{2}{*}{\multicolumn{10}{|c|}{$\begin{array}{l}\text { Number of Family } \\
\text { Members }\end{array}$}} \\
\hline & & & & & & & & & \\
\hline$<5$ & 101 & 81 & 23 & 19 & 124 & 100 & \multirow[t]{2}{*}{7.11} & $3.55-$ & \multirow{2}{*}{$<0.001$} \\
\hline$\geq 5$ & 29 & 38 & 47 & 62 & 76 & 100 & & 14.34 & \\
\hline \multicolumn{10}{|l|}{ Water sources } \\
\hline Protected & 92 & 77 & 27 & 23 & 119 & 100 & \multirow[t]{2}{*}{3.85} & $2.00-$ & \multirow{2}{*}{$<0.001$} \\
\hline Open & 38 & 47 & 43 & 53 & 81 & 100 & & 7.45 & \\
\hline \multicolumn{10}{|l|}{ Sanitation } \\
\hline Adequate & 97 & 79 & 26 & 21 & 123 & 100 & \multirow[t]{2}{*}{4.97} & $2.54-$ & \multirow{2}{*}{$<0.001$} \\
\hline Inadequate & 33 & 43 & 44 & 57 & 77 & 100 & & 9.76 & \\
\hline \multicolumn{10}{|l|}{ History of Infectious } \\
\hline \multicolumn{10}{|l|}{ Disease } \\
\hline No & 101 & 79 & 26 & 21 & 127 & 100 & \multirow[t]{2}{*}{5.89} & $2.97-$ & \multirow{2}{*}{$<0.001$} \\
\hline Yes & 29 & 40 & 44 & 60 & 73 & 100 & & 11.72 & \\
\hline \multicolumn{10}{|l|}{ Food Consumption } \\
\hline \multicolumn{10}{|l|}{ Pattern } \\
\hline Various & 102 & 78 & 28 & 22 & 130 & 100 & 5.46 & $2.76-$ & $<0$ \\
\hline Not diverse & 28 & 40 & 42 & 60 & 70 & 100 & & 10.84 & $<0.001$ \\
\hline Hand Washing & & & & & & & & & \\
\hline Behavior & & & & & & & & & \\
\hline Done & 104 & 85 & 18 & 15 & 122 & 100 & 11.55 & $5.52-$ & $<0.001$ \\
\hline Not done & 26 & 33 & 52 & 67 & 78 & 100 & & 24.43 & \\
\hline
\end{tabular}

3. Multivariate analysis with a multilevel approach

Multivariate analysis is an analysis that can explain the effect of more than one independent variable on one dependent variable. The multivariate analysis used in this research is multilevel logistic regression analysis using the STATA 13 program.

Table 3 shows that the risk of stunting among children under five is increased for low maternal education <Senior high school $(b=3.43 ; 95 \% \mathrm{CI}=1.47$ to $5.40 ; \mathrm{p}=$ 0.001), low family income $(b=2.72 ; 95 \%$ 
$\mathrm{CI}=0.80$ to $4.64 ; \mathrm{p}=0.005)$, family members $\geq 5(b=2.26 ; 95 \% \mathrm{CI}=0.65$ to 3.87; $\mathrm{p}=0.006)$, unprotected water sources $(\mathrm{b}=02.28 ; 95 \% \mathrm{CI}=0.74$ to $3.83 ; \mathrm{p}=$ 0.004), poor sanitation $(b=2.66$; $95 \% \mathrm{CI}=$ 1.06 to $4.26 ; \mathrm{p}=0.001$ ), children under five had a history of infectious diseases $(b=$ 2.29; $95 \% \mathrm{CI}=0.70$ to $3.88 ; \mathrm{p}=0.005$ ), the pattern of food consumption did not vary $(b=2.39 ; 95 \% \mathrm{CI}=0.67$ to $4.11 ; \mathrm{p}=0.006)$, improper hand washing behavior $(\mathrm{b}=2.10$; $95 \% \mathrm{CI}=0.63$ to $3.56 ; \mathrm{p}=0.005$ ).
In the multilevel analysis of posyandu strata, the results obtained $\mathrm{ICC}=34.84 \%$. This indicator shows that the incidence of stunting under five is $34.84 \%$ determined by variables at the posyandu level. This figure is greater than the standard role of thumb size of $8-10 \%$, so the contextual influence shown from the multilevel analysis is very important to note. The table also shows $\mathrm{p}<0.009$. This means that the multilevel model is statistically significant different from the usual logistic regression model. The results of the complete multivariate analysis can be seen in table 3 .

Table 3. Multivariate logistic regression analysis of stunting factors (mother's education, family income, number of family members, water sources, sanitation, history of infectious diseases, food consumption patterns, and hand washing behavior) in under five

\begin{tabular}{|c|c|c|c|c|}
\hline \multirow{2}{*}{ Variable Independent } & \multirow{2}{*}{$\mathbf{b}$} & \multicolumn{2}{|c|}{$95 \% \mathrm{CI}$} & \multirow{2}{*}{$\mathbf{p}$} \\
\hline & & Lower limit & Upper limit & \\
\hline \multicolumn{5}{|l|}{ Fixed Effect } \\
\hline $\begin{array}{l}\text { Maternal education ( }<\text { Senior high } \\
\text { school) }\end{array}$ & 3.43 & 1.47 & 5.40 & 0.001 \\
\hline Family income (<average) & 2.72 & 0.80 & 4.64 & 0.005 \\
\hline Family members $(\geq 5)$ & 2.26 & 0.65 & 3.87 & 0.006 \\
\hline Water source (unprotected) & 2.28 & 0.74 & 3.83 & 0.004 \\
\hline Sanitation (inadequate) & 2.66 & 1.06 & 4.26 & 0.001 \\
\hline History of infectious disease (any) & 2.29 & 0.70 & 3.88 & 0.005 \\
\hline $\begin{array}{l}\text { Food consumption pattern (not } \\
\text { diverse) }\end{array}$ & 2.39 & 0.67 & 4.11 & 0.006 \\
\hline $\begin{array}{l}\text { Hand washing behavior (not done } \\
\text { properly) }\end{array}$ & 2.10 & 0.63 & 3.56 & 0.005 \\
\hline \multicolumn{5}{|l|}{ Random Effect } \\
\hline Strata Posyandu (constanta) & 1.75 & 0.29 & 10.42 & \\
\hline \multicolumn{5}{|l|}{$\mathrm{N}$ observation $=200$} \\
\hline \multicolumn{5}{|l|}{ Log likelihood $=-41.69$} \\
\hline \multicolumn{5}{|l|}{ LR test vs. logistic regression, } \\
\hline $\mathrm{p}=0.009$ & & & & \\
\hline $\mathrm{ICC}=34.84 \%$ & & & & \\
\hline
\end{tabular}

\section{DISCUSSION}

1. The effect of mother's education on the incidence of stunting

Parents' education affects the incidence of stunting among children under five, especially in the education of mothers as the primary caregivers for toddlers. The results of the analysis showed that maternal education had an effect on the incidence of stunting in children under five and was statistically significant. Mothers with low education $<$ Senior high school have a risk 
of having children under five years of stunting 3.43 times greater than mothers with higher education $>$ Senior high school. The results of this study are in line with the research of Rahayu and Khairiyati (2014), namely that mothers with low education have a 5.1 times greater risk of children under two years of stunting compared to mothers who have higher education.

The low level of education of the mother makes it difficult for the mother to receive the information provided so that the knowledge of parenting and feeding patterns for babies and children is less (Yisak et al., 2015; Aridiyah et al., 2015). Low knowledge of maternal nutrition has a 3.3 times greater risk of experiencing stunting compared to mothers with good nutriational knowledge (Torlesse et al., 2016).

\section{The effect of family income on the incidence of stunting}

Families with low socioeconomic conditions or the occurrence of poverty are an indicator of a family's inability to get enough food, due to the low purchasing power to meet basic needs such as food, clothing, shelter and education. Family income affects the incidence of stunting in children under five. The analysis showed that there was an effect of family income on the incidence of stunting in children under five and it was statistically significant. Low family income <average risk of having a child under five is stunted by 2.72 times greater than families with high income> average. The results of this study are in line with research conducted by Yisak et al., (2015) in Eastern Ethiopia, found that families with an income below the minimum standard of 250 thousand rupiah per month are 2.5 times more likely to have a stunting child.

Toddlers with low-income families have 2.8 times the risk of getting stunted compared to toddlers with high family income (Torlesse et al., 2016). Family income is a measure of the family's ability to meet family needs, both food needs, as well as proper sanitation facilities for the family, so that families with low income $<$ average will find it difficult to meet the standard of family needs, this has an impact on children under five who are cared for by the family. low-income families become stunted.

\section{The effect of the number of family members on stunting}

The number of family members affects the food intake consumed by the family, including toddlers. The number of family members affects the incidence of stunting in children under five. The results of the analysis showed that the number of family members had an effect on the incidence of stunting in children under five and it was statistically significant. Families with $>5$ family members have a risk of having children under five with stunting by 2.26 times greater than families with $<5$ members. The results of this study are in line with research by Yisak et al., (2015), where a family with $>6$ members has a risk of their child experiencing stunting by 2 times greater. In Oktarina and Sudiarti's research (2013), it is said that the large number of family members increases the risk of stunting by 1.38 times compared to the number of small family members.

The number of family members has a large effect on the food intake given to the family. The fulfillment of nutrition in the family will be divided among many members, so that children under five in the family are at risk of stunting.

\section{The effect of water sources on the incidence of stunting}

Domestic water sources affect the incidence of stunting among children under five. The analysis showed that there was an effect of water sources in the household on the inci- 
dence of stunting in children under five and it was statistically significant. Families with open water sources have a risk of having children under five with stunting by 2.28 times greater than families with closed water sources. The results of this study are in line with the research of Chirande et al., (2015) which states that unprotected water sources increase the risk of stunting in Tanzania, namely 1.58 times compared to families who have protected water sources. In another study, it was said that unprotected water sources had three times the risk of children under five being stunted compared to families using clean water (Yisak et al., 2015). Clean drinking water sources are an important factor for body health and reduce the risk of various diseases such as diarrhea, cholera and typhus (Oktarina and Sudiarti, 2013). Diarrheal disease is closely related to poor clean water quality, long-term impact of morbidity and increased cases of stunting.

\section{The effect of sanitation on the incidence of stunting}

Poor sanitation will have an impact on increasing diseases such as diarrhea and worm infections which can be linked to the incidence of malnutrition. Unsafe sanitation generally occurs in poor and middleincome countries and areas with population densities that indirectly pose a threat to stunting for children (Spears et al., 2013). Household sanitation affects the incidence of stunting among children under five. The results of the analysis show that there is an effect of sanitation in the household on the incidence of stunting in children under five and it is statistically significant. Poor sanitation in a household has a risk of having children under five with stunting by 2.66 times greater than households or families with adequate sanitation. The results of this study are in line with study conducted by Cahyono et al., (2016) which states that poor environmental sanitation has a 3.9 times greater risk for children under five to experience stunting compared to the use of good environmental sanitation.

Poor sanitation is also a factor in the occurrence of stunting in the areas of Bali and East Nusa Tenggara (NTT), babies under two years who live in poor sanitation are at 1.46 times risk of experiencing stunting (Nadiyah et al., 2014). Sanitation in the family is related to the availability of adequate latrines, sewage systems, sewer systems and drinking water treatment. Households with unhealthy sanitation and latrines have a 3.4 times risk of having stunted children compared to households with sanitation and healthy latrines (Torlesse et al., 2016). Poorly managed sanitation also results in waste pollution and lack of clean water availability, so that it has a significant effect on the incidence of stunting in children under five..

\section{The effect of history of infectious disease on stunting}

A history of infectious diseases affects the incidence of stunting in children under five, diseases such as diarrhea and ARI will affect weight and growth of children under five. The results of the analysis showed that there was an effect of a history of infectious disease that had been experienced by children under five on the incidence of stunting in children under five and was statistically significant. Toddlers with a history of infectious diseases had a 2.29 times greater risk of stunting than toddlers without a history of infectious diseases. The results of this study are in line with previous studies, namely toddlers with a history of infectious diseases have a 2.2 times risk of getting stunted compared to toddlers who do not have a history of infectious diseases (Arifin et al., 2012). Based on the results of a study conducted by Lestari et al (2014), it was found that children suffering from ARI in 
the last 2 months had a risk of 5.7 times for stunting, while children who had diarrhea in the last 2 months had a 5.04 times risk of becoming stunting.

Infectious diseases, especially diarrhea, are closely related to access to clean water in households. Nematode infections can be caused by parasitic worms (roundworms, whipworms, and hookworms) which can affect the absorption of nutriational intake in toddlers, so that in the long term it causes stunting.

\section{The effect of food consumption patterns on stunting}

Food consumption patterns in the family can affect the nutritional status of children under five, especially in terms of nutritional adequacy rates for children under five. The results of the analysis show that there is an effect of food consumption patterns in families on the incidence of stunting in children under five and it is statistically significant. Families with non-diverse Food Consumption Patterns have a risk of stunting by 2.39 times greater than families with diverse Food Consumption Patterns. The results of this study are in line with Motbainor et al., (2015) which states that families experiencing food insecurity or lack of food diversity have a risk of child stunting 1.62 times compared to families with adequate food consumption patterns.

Food consumption patterns include a sufficient level of energy generated from food diversity and especially animal protein. Families with low animal protein adequacy increased the risk of stunting by 1.14 times, while low levels of fat consumption increased the risk of stunting by 1.64 times (Oktarina and Sudiarti, 2013). In toddlers who lack animal protein and fat in the long term it results in stunting.

\section{The effect of hand washing beha- vior on the incidence of stunting}

Hand washing behavior factors have an important effect on nutritional problems, one of which is stunting, although it is not a direct factor. Bad hand washing behavior will make it easier for toddlers to catch infectious diseases such as diarrhea and ARI. The results of the analysis showed that there was an effect of hand washing behavior on the incidence of stunting in infants and it was statistically significant. Mothers who do not wash their hands properly have a 2.10 times greater risk of stunting than mothers who regularly wash their hands properly. This is in line with Torlesse et al., (2016) which states that households who do not apply hand washing using soap have a 1.3 times greater risk of child stunting compared to households that apply washing hands using soap.

Another study states that hand washing can be protective for the incidence of stunted children, this is because mothers who regularly wash their hands using soap can reduce the risk of stunting by 0.43 times less than mothers who do not wash their hands (Rose et al., 2015). Washing hands that are not practiced by mothers or caregivers when caring for toddlers, especially when providing food, will make it easier for toddlers to catch infectious diseases such as diarrhea and ARI. Both of these diseases have a direct effect on stunting.

\section{The effect of Posyandu strata on the incidence of stunting}

The results of the analysis showed that posyandu strata had an effect on the incidence of stunting in children under five and was statistically significant. The results showed that the ICC $=34.84 \%$. This indicator shows that the posyandu condition at each stratum has a contextual effect on the incidence of stunting in children under five by $34.84 \%$. This figure is greater than the stan- 
dard rule of thumb size of $8-10 \%$, so the environmental influence, namely the posyandu strata, which is shown from the multilelevel analysis, affects the incidence of stunting in children under five. This is in line with previous research which states that posyandu has a contextual effect on the incidence of stunting children with ICC: $15.00 \%$ which means that the posyandu strata affect the incidence of stunting children, the posyandu level independently can reduce the incidence of stunting (Sajalia et al., 2018).

Toddlers who rarely come to the posyandu in the last 3 months have a higher chance of developing stunting, besides stunting it is also higher in children who do not have a growth monitoring card (Sahanggamu et al., 2017). Growth monitoring programs can prevent toddlers from stunted growth through early detection by health cadres and health workers at the posyandu.

\section{AUTHOR CONTRIBUTION}

Anna Mariyana, Yulia Lanti Retno Dewi, Setyo Sri Rahardjo, collected the data, did data analysis, and wrote the paper.

\section{CONFLICT OF INTEREST}

We declare that there was no conflict of interest.

\section{FUNDING AND SPONSORSHIP}

Insert your text here

\section{ACKNOWLEDGEMENT}

There was no external fund.

\section{REFERENCE}

Aridiyah FO, Ninna R, Mury R (2015). The factors affecting stunting on toddlers in rural and urban areas. E-Jurnal Pustaka Kesehatan. 3(1). https://jur-
nal.unej.ac.id/index.php/JPK/article/view/2520.

Ariesthi K, Tresna A, Wirawan DN (2015). Risk factors of moderate and severe malnutrition among children under five years old in East Nusa Tenggara. Public Health and Preventive Medicine Archive. 3(1): 1-33. https://dx.doi.org/10.24843/PHPMA.2015.v03.i 01.p04.

Arifin DZ, Sri Y, Hadyana S (2012). Analisis sebaran dan faktor risiko stunting pada balita di Kabupaten Purwakarta (Analysis of the distribution and risk factors of stunting in toddlers in Purwakarta Regency). Jurnal Epidemiologi Komunitas. 5(1): 1-9.

Audrie L, Benjamin F, Sadia A, Rie G, Tarique M, Rashidul H, Rubhana R, et al. (2013). Household enviromental conditions are associated with enteropathy and impaired growth in rural Bangladesh. The American Society Of Tropical Medicine and Hygiene. 89 (1): 130-137. https://dx.doi.org/10.4269\%2Fajtmh.12-0629.

Cahyono F, Stefanus PM, Intje P (2016). Stunting determinants of under five years children in various ecosystem zones in Kupang. Jurnal Gizi dan Pangan. 11(1): 9-18. https://doi.org/10.25182/jgp.2016.11.1.\%25p.

Chirande L, Deborah C, Hadijah M, Rose V, Sabas K, Abukari I, Surinder B, Michael D, Kingsley A (2015). Determinants of stunting and severe stunting among under-fives in Tanzania: evidence from the 2010 cross-sectional household survey. BMC Pediatrics. 15(165): 1-13. https://doi.org/10.1186/s12887-015-0482-9.

Demirchyan A, Petrosyan V, Sargsyan V Hekimian K (2016). Predictors of stunting among children ages o to 59 months in rural region of Armenia. $\mathrm{J}$ 
Mariyana et al./ Contextual Effect of Posyandu on the Risk of Stunting

Pediatr Gastroenterol Nutr. 62(1): 151-15. https://doi.org/10.1097/mpg.o000000000000901.

Kemenkes RI (2016a). Situasi balita pendek di Indonesia (Situation of short toddler in Indonesia). http://www.depkes.go.id/resources/download/pusdat in/infodatin/situasi-balita-pendek2016.pdf. Diakses Desember 2017.

Kemenkes RI (2016b). Situasi Gizi di Indonesia. http://www.depkes.go.id/resources/download/pusdatin/infodatin/s ituasi-gizi-indonesia-2016.pdf.

Diakses Oktober 2018.

Ki-Moon B (2016). SUN movement strategy and roadmap (2016-2020). http://= docs.scalingupnutrition.org/wpconte nt/uploads/2016/o9/strategy2016in-a-second.pdf Diakses desember 2017

Lestari W, Ani M, Zen R (2014). Faktor risiko stunting pada anak umur 6-24 bulan di Kecamatan Penanggalan Kota Subulussalam Provinci Aceh (Risk factors for stunting in children aged 6-24 months in the district of Penanggalan, Subulussalam, Aceh Province). Jurnal Gizi Indonesia. 3 (1): 37-45. https://doi.org/10.14710/jgi.3.1.126-134.

Motbainor A, Alemayehu, Abera K (2015). Stunting is associated with food diversity while wasting with food insecurity among underfive children in East adan West Gojjam Zones Of Amhara Region, Ethiopia. Plos One. 10(8): 114. https://dx.doi.org/10.1371\%2Fjournal.pone.0133542.

Mufida L (2015). Prinsip dasar makanan pendamping air susu ibu (MP-ASI) untuk bayi 6-24 bulan (Basic principles of complementary breastfeeding for infants 6-24 months). Jurnal Pangan dan Agroindustri. 13(4):
1646-1651. https://jpa.ub.ac.id/index.php/jpa/article/view/290/300.

Nadiyah, Dodik B, Drajat M (2014). Risk factors of stunting among 0-23 month old children in Bali Province, West Java and East Nusa Tenggara. Jurnal Gizi dan Pangan. 9(2): 125-132. https://doi.org/10.25182/jgp.2014.9. $2 . \% 25 \mathrm{p}$

Oktarina Z, Sudiarti T (2013). Risk factors of stunting among children (24-59 months) in Sumatera. Jurnal Gizi dan Pangan. 8(3): 175-180

Prendergast AJ, Humphrey JH (2014). The stunting syndrome in developing countries. Pediatrics and International Child Health. 34(4): 251-26. https://dx.doi.org/10.1179\%2F20469 05514Y.0000000158.

Rahayu A, Khairiyati L (2014). Maternal education as risk factors stunting of child 6-23 months-old. Jurnal Penelitian Gizi dan Makanan. 37(2): 129136. https://dx.doi.org/10.22435/pgm.v37i2.4016.129-136.

Riskesdas (2018). Riset Kesehatan Dasar Tahun 2018. Badan Penelitian dan Pengembangan Kesehatan Kementrian Kesehatan RI (Research and Development Agency for Health Ministry of Health RI). http://www.depkes.go.id/resources/download/general/H asil\%20Riskesdas\%202018.pdf. Diakses November 2018

Rose ES, Meridith B, Lazaro GC, Elisee N, Ann FG, Melanie L, Omo O, Sten HV, Troy DM (2015). Determinants of undernutrition among children aged 6-59 months in rural Zambezia Province, Mozambique: Results of two population-bass serial cross-Sectional Surveys. BMC Nutr. 1: 41. https://www.ncbi.nlm.nih.gov/pubmed/2718 2448. 
Sahanggamu PD, Lupi P, Drupadi D (2017). Information exposure and growth monitoring favour child nutrition in Rural Indonesia. Asia Pasific Journal Clinic Nutrtition. 26(2): 313-316

Sajalia H, Dewi YLR, Bhisma M (2018). Life course epidemilogy on the determinants os stunting children under five in East Lombok, West Nusa Tenggara. J Matern Child Health. 3(4): 242-251. https://doi.org/10.26911/thejmch.20 18.03.04.01.

Spears D, Arabinda G, Oliver C (2013). Open defection and chilhood stunting in India: An ecological of new data from 112 districts. Plos ONE. 8(9): e73784. https://doi.org/10.1371/journal.pone.0073784.

Sujendran S, Senarath U dan Joseph J (2015). Prevalence of stunting among children aged 6 to 36 months, in the Eastern Province of Sri Langka. Nutrition Disorders And Theraphy. 5 (1): 16. DOI: 10.4172/2161-0509.1000154.

Tim Nasional Percepatan Penanggulangan Kemiskinan (TNP2K) (2017). 100 Kabupaten/Kota Prioritas Untuk Intervensi Anak Kerdil (Stunting) (100 Priority Districts / Cities for Stunting
Intervention). Sekretariat Wakil Presiden Republik Indonesia. http://www.tnp2k.go.id/images/uploads/dow nloads/Buku\%20Ringkasan\%20Stunt ing.pdf Diakes Desember 2017.

Torlesse H, Aidan A C, Susy K, Robin N (2016). Determinants of stunting in Indonesia children: Evidence from a cross-sectional survey indicate a prominent role for the water, sanitation and hygiene sector in stunting reduction. BMC Public Health. 16 (669): 111. https://doi.org/10.1186/s12889-o16-3339-8.

Vonaesch P, Laura T, Sebastien B, Petula B, Liem B, Luong N, Thierry F, Alain F (2017). Factors associated with stunting in healthy children aged 5 years and less living in Bangui (RCA). PLoS ONE. 12 (8):1-17. https://doi.org/10.1371/journal.pone.0182363.

Yisak H, Tesfaye G, Firehiwot M (2015). Prevalence and risk factors for undernutrition among children under five at Haramaya District, Eastern Ethiopia. BMC Pediatrics. 15(212): 1-7. https://doi.org/10.1186/s12887-0150535-0. 